\title{
Topical Vitamin E
}

National Cancer Institute

\section{Source}

National Cancer Institute. Topical Vitamin E. NCI Thesaurus. Code C67081.

A topical preparation of a natural fat-soluble vitamin with potential antioxidant and cytoprotective activity. As a potent antioxidant and radical scavenger, vitamin $\mathrm{E}$ ameliorates free-radical damage to cell membranes, thereby protecting cells from reactive oxygen species and maintaining the integ rity of cellular macromolecules. In addition, vitamin E noncompetitively inhibits cyclooxygenase (COX) activity in many tissues, which may decrease inflammation. Vitamin $E$ is a generic name for a group of compounds known as tocopherols and tocotrienols (tocols). 